\title{
Travel plans for new developments: A global review
}

Chris De Gruyter ${ }^{a^{*}}$, Geoffrey Rose ${ }^{a}$, Graham Currie ${ }^{a}$, Tom Rye ${ }^{b}$ and Emilie van de Graaff c

${ }^{a}$ Monash Institute of Transport Studies, Department of Civil Engineering Monash University, Clayton, Victoria, Australia

${ }^{\mathrm{b}}$ Transport Research Institute, Edinburgh Napier University, Edinburgh, Scotland

' Yarra Trams, Melbourne, Victoria, Australia

${ }^{*}$ Corresponding author:

Phone: +61 399053894

Email: chris.degruyter@monash.edu

Manuscript prepared for: Transport Reviews

Manuscript ID: TTRV-2016-0194.R1

Date of submission: 14 April 2017

Word count: 6,772 words (excluding references) 


\section{Travel plans for new developments: A global review}

A travel plan is a mechanism for delivering a package of transport measures at a site to manage car use and encourage the use of more sustainable forms of transport. In recent years, travel plans have been required for new infill and greenfield developments through the land use planning and approvals process, predominantly in the United Kingdom, United States, continental Europe and Australia. This paper contributes to the literature by providing a global review of travel plans for new developments. The results show that while travel plans for new developments share a common set of elements with those for pre-existing sites, differences within each element are notable, particularly in the types of travel plan measures adopted, processes for managing the travel plan, and approaches to monitoring and review. Results of previous evaluations have varied considerably, although most have reported a reduction in car driver trips of 10-20 percentage points. Despite this, most evaluations lack rigour, with a paucity of robust evidence. Key success factors identified by the literature, such as the provision of an explicit policy supporting the role of travel plans, should be embedded within the travel planning process where possible to ensure best outcomes for new developments.

Keywords: travel plan; new development; travel demand management; sustainable transport; land use planning

\section{Introduction}

A travel plan is a mechanism for delivering a package of transport measures at a site to manage car use and encourage the use of more sustainable forms of transport, including walking, cycling and public transport (Enoch 2012). Travel plans are also known as Travel Demand Management (TDM) plans, trip reduction plans, mobility management plans and green transport plans (Enoch \& Rye 2006). 
Travel plans can be developed for different land uses including offices (Cairns et al. 2010), schools (Smith 2010), universities (Curtis \& Holling 2004), hospitals (Khandokar et al. 2013), residential housing (De Gruyter et al. 2015b), railway stations (ATOC 2013), airports (Ison et al. 2014), shopping centres (Woodruff \& Hui 2010), sporting venues (Currie \& Delbosc 2011), tourist attractions (Guiver \& Stanford 2014) and mixed-use developments (Wiblin et al. 2012). Measures included within travel plans can be wide-ranging; examples include bicycle parking, discounted public transport tickets, car parking supply restrictions, car sharing facilities, and customised information on local transport options (Cairns et al. 2004; De Gruyter 2017; De Gruyter et al. 2014a). Travel plans have traditionally been prepared by organisations on a voluntary basis in response to site related transport issues, such as car parking pressures, site access limitations and localised traffic congestion (Enoch 2012). However, they are also seen to offer a range of potential health and well-being benefits through increased walking and cycling (Petrunoff et al. 2016a), and can also contribute to wider goals around reducing air pollution and greenhouse gas emissions (Transport for London 2011).

While travel plans are most commonly prepared for pre-existing sites, they can also be required for new infill and greenfield developments as a condition of planning consent (Rye et al. 2011a). The use of the planning system to require travel plans, as opposed to their traditional voluntary preparation, represents a key difference between travel plans for new developments and those for pre-existing sites. However, this can present a number of challenges, particularly around implementation given that the travel plan is no longer a voluntary undertaking (De Gruyter et al. 2015a).

To date, research into travel plans has predominantly focused on pre-existing sites, particularly key trip generators such as workplaces and schools (De Gruyter 2017; De Gruyter et al. 2014b), with a number of systematic literature reviews published on the topic (Macmillan et al. 2013; Moghtaderi et al. 2012; Petrunoff et al. 2016a). However, relatively little research 
has been undertaken on travel plans specifically for new developments, with no published synthesis of the literature available. This paper $^{1}$ aims to fill this gap through providing an international review of the literature on travel plans for new developments. Specific research objectives include:

(1) To develop an understanding of their key characteristics and issues associated with their development, implementation and monitoring

(2) To understand where and how they have been required through the planning process, and the implications this has for travel planning practice

(3) To synthesise previous evaluations of their effectiveness and identify key success factors.

The contribution of this paper is a global review of past and current trends in travel planning for new developments, with recommendations to guide future practice and policy in this field. This paper uses the term 'new development' to refer to any new or expanded building/s located within an infill or greenfield site.

This paper is structured as follows. The next section describes the research method used to undertake the review. An overview of the key characteristics of travel plans for new developments is then presented, including issues associated with requiring them through the planning process. The geographical coverage and scope of travel plans for new developments is then detailed. This is followed by a synthesis of travel plan evaluations and a summary of key success factors. A discussion of key recommendations for the future is then provided, followed by a set of concluding remarks.

\footnotetext{
${ }^{1}$ An earlier version of this paper was presented at the Transportation Research Board (TRB) $96^{\text {th }}$ Annual Meeting in Washington, D.C, in January 2017.
} 


\section{Research method}

In order to meet the research aim and objectives, a literature review of academic research papers and industry reports relating to travel plans for new developments was undertaken. The method used to source literature included searching for relevant publications in various databases including Scopus, ScienceDirect, Transportation Research Information Documentation (TRID) and World Transit Research. A number of different search terms were used including travel plan, green transport plan, trip reduction plan, employer transport plan, transportation demand management plan, travel demand management plan, TDM plan, and mobility management plan. The authors also drew upon their knowledge and experience with travel plans to source additional literature. Following an initial scan of publications, a snowballing technique was adopted whereby additional literature was identified through the citations made in each publication (Van Wee \& Banister 2016). No limitation was placed on the geographies from which relevant literature was sourced.

Following a review of the title, abstract and reference list for each publication, a total of 191 publications were deemed relevant to travel plans. However, only 47 of these focused specifically on new developments and therefore provided the main basis for the review. A number of the remaining 144 publications were used to provide context as needed, particularly in illustrating how travel plans for new developments differ to those at pre-existing sites.

Table 1 details the types of publications that were sourced for the literature review. Across all 191 publications that were relevant to travel plans, most were either journal articles (37.7\%) or conference papers (20.9\%). However, research reports (13.6\%) and guidelines (13.1\%) also comprised a sizeable proportion of the literature. A similar pattern was found for the 47 publications that were specific to new developments, although a greater proportion were journal articles (44.7\%), with less conference papers available (8.5\%). Table 2 indicates the years in which the literature was published, showing that most of the 191 publications on travel 
plans were from 2001-15. However, those specific to new developments were found to be mostly published from 2006 onwards, thereby reflecting the more recent nature of research in this field.

Table 1. Publications sourced for the literature review, by type.

\begin{tabular}{lllll}
\hline \multirow{2}{*}{ Type } & \multicolumn{2}{c}{ Publications relevant to travel plans } & \multicolumn{2}{l}{ Publications specific to new developments } \\
\cline { 2 - 5 } & Number & Percentage (\%) & Number & Percentage (\%) \\
\hline Journal article & 72 & $37.7 \%$ & 21 & $44.7 \%$ \\
\hline Conference paper & 40 & $20.9 \%$ & 4 & $8.5 \%$ \\
\hline Book/book chapter & 6 & $3.1 \%$ & 3 & $6.4 \%$ \\
\hline Research report & 26 & $13.6 \%$ & 7 & $14.9 \%$ \\
\hline Other report & 18 & $9.4 \%$ & 4 & $8.5 \%$ \\
\hline Guidelines & 25 & $13.1 \%$ & 7 & $14.9 \%$ \\
\hline Web page & 4 & $2.1 \%$ & 1 & $2.1 \%$ \\
\hline Total & $\mathbf{1 9 1}$ & $\mathbf{1 0 0 . 0} \%$ & $\mathbf{4 7}$ & $\mathbf{1 0 0 . 0} \%$ \\
\hline
\end{tabular}

Table 2. Publications sourced for the literature review, by year.

\begin{tabular}{lllll}
\hline \multirow{2}{*}{ Year } & \multicolumn{2}{c}{ Publications relevant to travel plans } & \multicolumn{2}{c}{ Publications specific to new developments } \\
\cline { 2 - 5 } & Number & Percentage (\%) & Number & Percentage (\%) \\
\hline 1995 or earlier & 7 & $3.7 \%$ & 1 & $2.1 \%$ \\
\hline $1996-2000$ & 14 & $7.3 \%$ & 1 & $2.1 \%$ \\
\hline $2001-2005$ & 36 & $18.8 \%$ & 4 & $8.5 \%$ \\
\hline $2006-2010$ & 59 & $30.9 \%$ & 12 & $25.5 \%$ \\
\hline $2011-2015$ & 67 & $35.1 \%$ & 24 & $51.1 \%$ \\
\hline 2016 and beyond & 8 & $4.2 \%$ & 5 & $10.6 \%$ \\
\hline Total & $\mathbf{1 9 1}$ & $\mathbf{1 0 0 . 0} \%$ & $\mathbf{4 7}$ & $\mathbf{1 0 0 . 0} \%$ \\
\hline
\end{tabular}

The review did not include the use of personalised journey planning programs that are typically delivered to households in defined geographical areas. These programs come under various names such as individualised marketing and travel blending (Brög et al. 2009; James et al. 
2017; Rose \& Ampt 2001). They are considered different to travel plans in that they represent a specific voluntary travel behaviour change initiative, usually delivered to households as a one-off intervention. This is in contrast to a travel plan which involves the delivery of a set of transport initiatives over time (De Gruyter 2017; Enoch 2012).

\section{Key characteristics of travel plans for new developments}

Travel planning guidance generally recommends the inclusion of specific elements within a travel plan, regardless of whether it is for a pre-existing site or new development (ACT Canada \& Noxon Associates Limited 2010; City and County of San Francisco 2016b; Department for Transport 2009; Department of Infrastructure 2008; NZ Transport Agency 2011; Transport for London 2011). These elements typically include context for the travel plan, existing transport conditions, travel plan objectives, targets and indicators, travel plan actions/measures, arrangements for managing the travel plan, and mechanisms for monitoring and review.

Based on the literature, Table 3 provides a description of each element and shows how these compare for pre-existing sites and new developments. Context for the travel plan usually includes a statement about the motivation for the travel plan, with planning requirements often being a key driver for new developments (Dill 1998; Khandokar et al. 2013; Roby 2010b). Existing transport conditions for pre-existing sites are usually informed by a baseline travel survey of site users. However, this is often not possible with new developments as the site may not yet be occupied or even built (De Gruyter 2017; De Gruyter et al. 2014b); the general exception to this is a building extension where future/additional occupants may have similar travel patterns to existing occupants. Travel plan objectives can also differ between pre-existing sites and new developments; the latter often aligned with the intent of the planning requirement and the former taking more of a bottom-up approach through the involvement of site users (Howlett \& Watson 2010). Targets and indicators for new developments may, in some cases, 
be linked to sanctions/fines if not met, while pre-existing sites may focus more on alignment to organisational goals and priorities (Roby 2010b). The actions/measures within a travel plan may be more infrastructure-based for new developments (e.g. bicycle parking) and can also include contributions towards public transport services, while pre-existing sites may focus more on travel behaviour change initiatives where infrastructure is already in place (De Gruyter et al. 2014a). For new developments, the property developer usually plays a key role in the initial management of the travel plan, although this is ideally handed over at some point to a travel plan coordinator to ensure the travel plan becomes embedded at the site (Roby 2010a). Monitoring and review also differ between pre-existing sites and new developments, particularly where no baseline comparison is available for new developments (De Gruyter 2017; De Gruyter et al. 2015c). In addition to these differences, travel plans for pre-existing sites are normally undertaken on a voluntary basis while those for new developments are usually mandatory under a planning condition or agreement (Addison \& Associates 2008). In sum, the differences in Table 3 suggest that travel planning for new developments should not be undertaken in the same way as that for pre-existing sites; a tailored approach is therefore required. 
Table 3. Comparison of travel plan elements for pre-existing sites and new developments.

\begin{tabular}{|c|c|c|c|}
\hline Element & Description & Pre-existing site & New development \\
\hline Context & $\begin{array}{l}\text { Site characteristics, } \\
\text { motivations and policies }\end{array}$ & $\begin{array}{l}\text { Number and type of site users } \\
\text { are known; existing transport } \\
\text { policies may already be in place }\end{array}$ & $\begin{array}{l}\text { Number and type of site users may } \\
\text { be unknown; motivation may be } \\
\text { driven by planning requirement } \\
\text { and/or by parking norms }\end{array}$ \\
\hline $\begin{array}{l}\text { Existing } \\
\text { transport } \\
\text { conditions }\end{array}$ & $\begin{array}{l}\text { Surrounding transport } \\
\text { networks and services, } \\
\text { existing travel patterns }\end{array}$ & $\begin{array}{l}\text { Baseline travel survey usually } \\
\text { conducted to inform the } \\
\text { development of the travel plan }\end{array}$ & $\begin{array}{l}\text { Baseline survey not possible as site } \\
\text { not usually occupied; main focus is } \\
\text { on surrounding transport network } \\
\text { and the Transport Impact } \\
\text { Assessment }\end{array}$ \\
\hline Objectives & $\begin{array}{l}\text { Statements about what the } \\
\text { travel plan intends to achieve }\end{array}$ & $\begin{array}{l}\text { Site users often involved in } \\
\text { shaping objectives in response } \\
\text { to baseline survey findings }\end{array}$ & $\begin{array}{l}\text { Objectives may respond to intent of } \\
\text { planning requirement but also } \\
\text { reflect wider transport policy goals }\end{array}$ \\
\hline $\begin{array}{l}\text { Targets and } \\
\text { indicators }\end{array}$ & $\begin{array}{l}\text { Measures used to determine } \\
\text { whether the travel plan is } \\
\text { meeting its objectives }\end{array}$ & $\begin{array}{l}\text { May cover both outcomes and } \\
\text { outputs, but also awareness and } \\
\text { uptake of initiatives }\end{array}$ & $\begin{array}{l}\text { Likely to focus on outcomes and } \\
\text { may be linked to sanctions/fines if } \\
\text { targets are not met }\end{array}$ \\
\hline $\begin{array}{l}\text { Actions/ } \\
\text { measures }\end{array}$ & $\begin{array}{l}\text { Package of initiatives to be } \\
\text { delivered at the site to achieve } \\
\text { the travel plan objectives }\end{array}$ & $\begin{array}{l}\text { Mostly non-infrastructure } \\
\text { initiatives or less expensive } \\
\text { infrastructure (such as bicycle } \\
\text { parking and showers) that } \\
\text { respond to baseline survey } \\
\text { findings }\end{array}$ & $\begin{array}{l}\text { Mostly infrastructure initiatives } \\
\text { prior to occupation, with other } \\
\text { initiatives delivered thereafter; } \\
\text { could also include participation in } \\
\text { travel plan groups }\end{array}$ \\
\hline Management & $\begin{array}{l}\text { Roles and responsibilities, } \\
\text { timeframes and budget }\end{array}$ & $\begin{array}{l}\text { Usually involves existing } \\
\text { personnel at site with internal } \\
\text { budgets used to fund travel plan }\end{array}$ & $\begin{array}{l}\text { Developer (usually a consultant) } \\
\text { plays a key role initially; travel plan } \\
\text { coordinator may be appointed } \\
\text { before/upon occupation }\end{array}$ \\
\hline $\begin{array}{l}\text { Monitoring } \\
\text { and review }\end{array}$ & $\begin{array}{l}\text { Method for measuring } \\
\text { outcomes and ensuring travel } \\
\text { plan maintains relevance }\end{array}$ & $\begin{array}{l}\text { Annual travel surveys to track } \\
\text { progress; regular reviews and } \\
\text { updates of travel plan }\end{array}$ & $\begin{array}{l}\text { No baseline travel patterns } \\
\text { available; may include specific } \\
\text { monitoring requirements }\end{array}$ \\
\hline
\end{tabular}

Source: Authors’ synthesis of the literature (ACT Canada \& Noxon Associates Limited 2010; Addison \& Associates 2008; British Standards Institution 2008; Cairns et al. 2002; City and County of San Francisco 2016b; De Gruyter et al. 2015c; Department for Transport 2005, 2009; Department of Infrastructure 2008; Gammie \& Vandersar 2003; Hendricks 2008; Howlett \& Watson 2010; NZ Transport Agency 2011; PBAI 2005; Roby 2010b; Rye et al. 2011a; Seggerman \& Hendricks 2005; Transport for London 2011; Yeates \& Enoch 2013)

Perhaps reflecting their relative novelty, combined with the use of the planning process, a range of issues have arisen in requiring travel plans for new developments. Table 4 provides a 
synthesis of key issues identified by the literature. In considering the development of travel plans, a 'tick-box' approach by developers has been common where the sole objective is to seek planning approval (Rye et al. 2011a). This is coupled with travel plans of varying quality been submitted for approval (De Gruyter 2017; De Gruyter et al. 2014a), with planning officers often having little experience with assessing travel plans (Wynne 2015). Implementation is sometimes altogether lacking, particularly where there is little follow-up or enforcement (De Gruyter et al. 2015a; Rye et al. 2011a). There are also issues related to the ownership of travel plans, particularly where those responsible for implementation are not involved in the development of the travel plan (De Gruyter 2017; De Gruyter et al. 2015a). In terms of monitoring, a commonly cited issue has been the lack of available resources within local government for enforcement (De Gruyter 2017; De Gruyter et al. 2014b; Llewellyn et al. 2014). Frequently, there is also a lack of willingness on behalf of the local authority to set in place, prior to giving planning consent, a legally enforceable requirement on the implementation of the travel plan and its targets, particularly in areas which are seeking to attract developers to invest (Addison \& Associates 2008; MAX 2009). Given the issues identified in Table 4, the development, implementation and monitoring of travel plans for new developments may be less effective than anticipated. Despite this, travel plans have still been required for new developments in a number of countries, as discussed in the next section. 
Table 4. Key issues in requiring travel plans for new developments.

\begin{tabular}{|c|c|}
\hline Stage & Key issues \\
\hline Development & $\begin{array}{l}\text { - Travel plan may only be prepared to seek planning approval, with little commitment thereafter } \\
\text { - Travel planning guidance is not always tailored to new developments } \\
\text { - Travel plans of varying quality have been submitted and subsequently approved } \\
\text { - } \text { - Type of development and end-user is sometimes unknown, making it difficult to develop an } \\
\text { appropriate set of objectives, targets and measures for the travel plan }\end{array}$ \\
\hline Implementation & $\begin{array}{l}\text { - Travel plan measures are not implemented in some cases } \\
\text { - Lack of suitable handover arrangements from the developer to site manager } \\
\text { - Travel plan objectives do not always align with the motivations of those responsible for } \\
\text { - Roles and responsibilities associated with implementing the travel plan are not always clear }\end{array}$ \\
\hline Monitoring & $\begin{array}{l}\text { - Lack of monitoring, leading to limited evidence of travel plan effectiveness } \\
\text { - Ability to enforce travel plans is hindered by insufficient resources within local government } \\
\text { - Roles and responsibilities associated with monitoring the travel plan are not always clear } \\
\text { - Concern that the developer may go elsewhere if travel plan requirements are too onerous }\end{array}$ \\
\hline
\end{tabular}

Source: Authors' synthesis of the literature (Addison \& Associates 2008; Angelo Planning Group \& Nelson Nygaard 2013; De Gruyter 2017; De Gruyter et al. 2014a, 2014b, 2015a; Enoch \& Ison 2008; Hendricks 2008; Llewellyn et al. 2014; MAX 2009; Roby 2010b; Rye et al. 2011a; Wynne 2015)

\section{Geographical coverage and scope}

This section considers where and how travel plans have been required for new developments. This includes a summary of past and current travel planning activity in relevant jurisdictions. While travel plans have been used in various forms since the 1970s in the United States, and the 1980s in the Netherlands and United Kingdom (Coleman 2000), their application to new developments mostly came about in the 1990s and early 2000s (Rye et al. 2011a). While this field is still emerging, activity is predominantly focused on the United Kingdom (Rye et al. 2011a), United States (Jollon 2013), continental Europe (Rye et al. 2011b) and Australia (De Gruyter 2017). Table 5 provides an overview of the scale of practice within each of those 
geographies, along with a summary of their scope in terms of land uses affected, mechanisms used to require travel plans, policy support and enforcement practices.

The United Kingdom has arguably had the highest level of travel planning activity for new developments across all geographies, with clear development thresholds used to specify when a travel plan is required (Transport for London 2011). In the Local Transport Plan (LTP) regime in place in England between 2001 and 2011, national guidance to local authorities on the content of their LTPs placed considerable emphasis on travel plans for both new and existing development. In addition, planning policy guidance that is a material consideration in both drawing up local spatial plans and making spatial planning decisions still emphasises the need for travel plans in new developments (Copsey 2012; Rye et al. 2011a). The existence between 2004 and 2011 of national maximum parking standards for all large developments was also a significant driver for travel plans in new developments (Rye et al. 2011b). However, issues with implementation have still been experienced, with Addison \& Associates (2008) noting that of the 233 workplace travel plans secured through the planning process between 2001 and 2006, only 36\% had been implemented (Addison \& Associates 2008). Part of this is seen to be related to limited enforcement and follow-up by local authorities (Addison \& Associates 2008; Rye et al. 2011a). An important conclusion from the experience of using the planning process to secure travel plans in England is that the local authority must have both the political will and the technical capacity (both in its transport planning team and its legal department) to use the planning system in this way. Those authorities who do so most are those with the technical capacity and also with significant economic growth pressures that generate political pressure to manage the impacts of development. Securing travel plans through the planning process, or indeed anything else that might be perceived as a burden on the developer, will be less of a priority in areas with lower economic growth and in such areas more 'lip service' may be paid to this requirement from national planning guidance (MAX 2009; Rye et al. 2011a). 
Table 5. Geographical coverage and scope of travel plans for new developments.

\begin{tabular}{|c|c|c|c|c|c|}
\hline Geography & Scale & Land uses & Mechanisms & Policy support & Enforcement \\
\hline United Kingdom & $\begin{array}{l}\text { High } \\
\text { Comprehensive national } \\
\text { guidance for travel plans for } \\
\text { new developments, with } \\
\text { significant activity } \\
\text { throughout both England and } \\
\text { Scotland }\end{array}$ & $\begin{array}{l}\text { Various } \\
\text { Generally applies to all land } \\
\text { uses, with development } \\
\text { thresholds specified for } \\
\text { when a travel plan is } \\
\text { required }\end{array}$ & $\begin{array}{l}\text { Planning obligations } \\
\text { (mostly) } \\
\text { Planning obligations (legal } \\
\text { agreements) are generally } \\
\text { used as they can be used to } \\
\text { secure payments and become } \\
\text { binding upon future owners; } \\
\text { conditions may also be used } \\
\text { to govern the provision or } \\
\text { operation of on-site transport } \\
\text { infrastructure }\end{array}$ & $\begin{array}{l}\text { High } \\
\text { National planning policy } \\
\text { provided a strong level of } \\
\text { support for travel plans, with } \\
\text { local authorities also } \\
\text { adopting similar policies }\end{array}$ & $\begin{array}{l}\text { Moderate } \\
\text { Limited resources available } \\
\text { within local government for } \\
\text { enforcement, yet travel plan } \\
\text { agreements typically } \\
\text { stipulate monitoring } \\
\text { requirements }\end{array}$ \\
\hline United States & $\begin{array}{l}\text { Moderate } \\
\text { Comprehensive } \\
\text { requirements in place but } \\
\text { limited to only some } \\
\text { counties and cities, e.g. } \\
\text { Arlington, Bloomington, } \\
\text { Boulder, Cambridge, } \\
\text { Fairfax, Montgomery, } \\
\text { Pasadena, Portland, } \\
\text { Rockville, San Francisco }\end{array}$ & $\begin{array}{l}\text { Various } \\
\text { Applies to most land uses, } \\
\text { although residential is } \\
\text { excluded in some } \\
\text { cities/counties; thresholds } \\
\text { are often specified for when } \\
\text { a travel plan is required }\end{array}$ & $\begin{array}{l}\text { Land deeds (mostly) } \\
\text { Land deeds (legal } \\
\text { agreements) generally } \\
\text { specify travel plan } \\
\text { requirements which become } \\
\text { binding upon future owners } \\
\text { and can affect developments } \\
\text { in perpetuity }\end{array}$ & $\begin{array}{l}\text { High } \\
\text { Strong requirements for } \\
\text { travel plans are stated in } \\
\text { municipal codes and plans of } \\
\text { the relevant jurisdictions }\end{array}$ & $\begin{array}{l}\text { High } \\
\text { Some counties and cities } \\
\text { (e.g. Fairfax) have staff } \\
\text { available for monitoring and } \\
\text { enforcing travel plans for } \\
\text { new developments }\end{array}$ \\
\hline
\end{tabular}




\begin{tabular}{|c|c|c|c|c|c|}
\hline Geography & Scale & Land uses & Mechanisms & Policy support & Enforcement \\
\hline \multirow[t]{2}{*}{ Continental Europe } & Low & Workplaces (mostly) & Various & Varies & Low \\
\hline & $\begin{array}{l}\text { Limited evidence of practice } \\
\text { in only some countries: } \\
\text { Belgium, Italy, Sweden, } \\
\text { Switzerland and the } \\
\text { Netherlands }\end{array}$ & $\begin{array}{l}\text { Belgium and Italy in } \\
\text { particular have placed a } \\
\text { focus on workplaces over a } \\
\text { given size }\end{array}$ & $\begin{array}{l}\text { Various mechanisms have } \\
\text { been used such as developer } \\
\text { agreements and conditions } \\
\text { on building/environmental } \\
\text { permits }\end{array}$ & $\begin{array}{l}\text { National policy supportive } \\
\text { of travel planning principles } \\
\text { is in place in only some } \\
\text { countries, e.g. Sweden, } \\
\text { Switzerland }\end{array}$ & $\begin{array}{l}\text { Limited evidence to suggest } \\
\text { enforcement is undertaken } \\
\text { following development } \\
\text { occupation }\end{array}$ \\
\hline \multirow[t]{2}{*}{ Australia } & Low & Various & Planning conditions & Low & Low \\
\hline & $\begin{array}{l}\text { Practice mainly limited to } \\
\text { some local governments in } \\
\text { the states of Victoria, New } \\
\text { South Wales and Western } \\
\text { Australia; local governments } \\
\text { in other states are still } \\
\text { considering requirements for } \\
\text { travel plans }\end{array}$ & $\begin{array}{l}\text { Mixed-use developments, } \\
\text { offices and hospitals; larger } \\
\text { focus on residential } \\
\text { developments in state of } \\
\text { Victoria }\end{array}$ & $\begin{array}{l}\text { (mostly) } \\
\text { Conditions on planning } \\
\text { permits are mostly used, } \\
\text { although formal legal } \\
\text { agreements have been used } \\
\text { in a small number of cases } \\
\text { which become binding upon } \\
\text { future owners }\end{array}$ & $\begin{array}{l}\text { Only some local } \\
\text { governments have written } \\
\text { requirements for travel plans } \\
\text { in their local planning } \\
\text { policies; no state or national } \\
\text { policy exists }\end{array}$ & $\begin{array}{l}\text { Limited resources available } \\
\text { within local government for } \\
\text { enforcement; no penalties or } \\
\text { fines have been applied } \\
\text { although permit conditions } \\
\text { and agreements are } \\
\text { enforceable }\end{array}$ \\
\hline
\end{tabular}

Source: Authors’ synthesis of the literature (ABC 2014; Addison \& Associates 2008; City and County of San Francisco 2016a, 2016b; Copsey 2012; De Gruyter 2017; De Gruyter et al. 2014a, 2014b; Enoch \& Potter 2003; Ho et al. 2015; Jollon 2013; MAX 2007; NSW Government 2011; Petrunoff et al. 2015; Petrunoff et al. 2016b; Potter \& Enoch 2007; RAC 2014; Rye et al. 2011a; Rye et al. 2011b; Stewart 1994; UrbanTrans \& Kimley Horn Associates 2014; Vanoutrive 2014; Vanoutrive et al. 2010; Wiblin et al. 2012) 
Unlike the United Kingdom, the United States has no national or state planning policy that refers to travel plans for new developments, although it is acknowledged that land use decisions in the United States are made almost exclusively by localities. Strong travel planning requirements are in place at the local level in the United States in some cities and counties; examples include Arlington, Boulder, Cambridge, Fairfax, Montgomery, Pasadena, and more recently, San Francisco (City and County of San Francisco 2016b; Jollon 2013; UrbanTrans \& Kimley Horn Associates 2014). Requirements for travel plans in each of these jurisdictions are generally specified in the respective municipal code or plan. In some cases, penalties and fines are set for non-compliance. For example, affected businesses in Seattle, Washington can be fined \$250/day for non-compliance, while employers in Cambridge, Massachusetts can be fined \$10 per parking space per day (ABC 2014; UrbanTrans \& Kimley Horn Associates 2014). However, it is not clear to what extent such penalties/fines are enforced in practice. In addition, travel plan requirements are typically written into individual land deeds with the intention that they become binding upon future owners and affect developments in perpetuity (UrbanTrans \& Kimley Horn Associates 2014).

Experience with travel planning in continental Europe, specifically for new developments, is less clear from the literature. However, both Italy and parts of Belgium require travel plans for all workplaces over a certain size (Enoch \& Potter 2003; Vanoutrive et al. 2010). These requirements would presumably apply also to new workplace developments, yet enforcement is understood to be limited (Potter \& Enoch 2007). In addition, Sweden and Switzerland have both moved beyond an ad-hoc approach to incorporating travel planning into the development process, while the Netherlands has used the environmental permit process to influence sustainable transport outcomes (MAX 2007; Rye et al. 2011b). In general, because planning law is more codified in continental European countries than in the United Kingdom, it is more problematic to adapt the use of that law to encourage and/or require travel plans for 
new developments (MAX 2009). For example, in the United Kingdom, national planning guidance has legal validity in planning decisions, but it is not in itself law and can therefore be made much more easily and quickly. Guidance with this semi-legal status is not possible to create in other legal systems. On the other hand, there are also various examples of car-free housing developments throughout Germany, Austria, the Netherlands and Denmark (De Gruyter 2017; Melia et al. 2013; Wright 2005). While these do not typically have formal travel plans in place, they often include related initiatives such as on-site car sharing facilities (Wright 2005), and once again, reduced parking requirements have been a driver for travel planning initiatives (such as car sharing clubs and high quality bike parking) at such locations.

As in the United States, the scale of practice in Australia is limited to only some local governments in certain states (De Gruyter et al. 2014b). Travel plans have been required mostly for residential developments in the state of Victoria (De Gruyter et al. 2014a), with examples of travel plans for new mixed-use developments, hospitals and offices in the state of New South Wales (Ho et al. 2015; NSW Government 2011; Petrunoff et al. 2013). Western Australia is still considering requirements for travel plans, although there is at least one reported example of where a travel plan was required for a hospital redevelopment (Wake 2007). Limited policy support is provided for travel plans in Australia, with only some local governments incorporating requirements into their local planning policies (De Gruyter et al. 2014b). Enforcement practices are also weak, with limited evidence of much follow-up at the post development occupation stage (De Gruyter et al. 2014b, 2015a).

There are also a number of other jurisdictions with some form of travel plan requirements, yet the literature on this is particularly limited. In New Zealand, a number of local governments require travel plans for new developments yet no regional or national policy explicitly refers to travel plans (Baker 2007). In Canada, some local governments in Ontario 
stipulate travel plan measures for new developments which can be used in supporting proposed reductions in car parking supply (Hill 2013).

In sum, the scale and scope of travel planning for new developments appears to vary considerably across each geography. The United Kingdom appear to be leaders in the field, followed closely by the United States. Other jurisdictions still in their infancy, such as Australia, can potentially learn much from the experience and approaches adopted in the United Kingdom and United States.

\section{Synthesis of evaluations and key success factors}

This section provides a synthesis of evaluations of travel plans for new developments and summarises key factors that are considered by the literature as integral to their success. However, it is first worth noting the inherent difficulty associated with evaluating travel plans for new developments. In contrast to travel plans at pre-existing sites, where travel behaviour is usually compared by way of a survey before and after travel plan implementation (Ampt et al. 2009), it is difficult to determine baseline/existing travel patterns for a new development as the site is not typically occupied or even built (De Gruyter 2017; De Gruyter et al. 2015c). While a before survey can be administered upon development occupation, some (or even most) travel plan measures may have been implemented prior to occupation, making it difficult to determine their impact (Stewart 1994). Alternative evaluation methods have therefore been proposed, with case-control designs considered to be more rigorous due to their ability to better control for external factors (De Gruyter 2017; De Gruyter et al. 2015c). This is in contrast to the more common method of comparing trip generation patterns at a site against published trip generation rates; the latter of which is often based on surveys undertaken in different locations and/or timeframes (De Gruyter et al. 2015c). However, the balance between rigour and pragmatism in evaluating travel plans is also acknowledged, particularly where suitable control 
sites are not available given the range of external factors that can influence travel behaviour such as car parking provision, availability of transport options and ‘self-selection' (De Gruyter 2017; De Gruyter et al. 2016). In such cases, comparisons to secondary data sources, such as published trip generation rates, may be the only realistic alternative to evaluating the travel plan.

A summary of evaluations of travel plans for new developments is provided in Table 6 for a range of land uses and geographies. The evaluations undertaken to date have each generally focused of a small number of case study sites, and in some cases, a single case study site. With the exception of only two studies (Arlington County Commuter Services 2013; De Gruyter et al. 2015c), all of the evaluations considered travel to/from the site by only the main user type (e.g. employees, not visitors, in the case of offices). Where evaluation results have been expressed in terms of a percentage change in car use, results have ranged from a reduction in car use of 5 percentage points to as much as 42 percentage points. This full range was exhibited by two hospital sites in Perth, Australia (Petrunoff et al. 2015). However, most of the evaluations reported a reduction in car use of around 10-20 percentage points (Baker 2007; Cairns et al. 2010; Copsey 2012; De Gruyter et al. 2015c; Petrunoff et al. 2016b; Rye et al. 2011b). It is also worth noting that some of the evaluations were based on comparisons of before and after travel survey data, in which some travel initiatives would have been presumably implemented prior to the before survey. Other evaluations made comparisons to secondary data sources such as published vehicle trip generation rates (Arlington County Commuter Services 2013; Spack et al. 2010) which are considered to be limited given differences in data collection periods. 
Table 6. Summary of evaluations of travel plans for new developments.

\begin{tabular}{|c|c|c|}
\hline Land use & Key findings & Level of evaluation rigour \\
\hline $\begin{array}{l}\text { Office (6 sites) } \\
\text { Minneapolis, United States (Spack et } \\
\text { al. 2010) }\end{array}$ & $\begin{array}{l}\text { Average vehicle trip generation in } \\
\text { peak periods across all sites was 36- } \\
37 \% \text { lower than published vehicle trip } \\
\text { generation rates } \\
\text { Average peak parking generation was } \\
21 \% \text { lower than published parking } \\
\text { generation rates }\end{array}$ & $\begin{array}{l}\text { Low: published vehicle trip } \\
\text { generation and parking rates are based } \\
\text { on surveys undertaken in different } \\
\text { years and locations to those conducted } \\
\text { at the six sites }\end{array}$ \\
\hline $\begin{array}{l}\text { Office (1 site) } \\
\text { New South Wales, Australia (NSW } \\
\text { Government 2011) }\end{array}$ & $\begin{array}{l}\text { Achieved } 45 \% \text { of employees } \\
\text { commuting by non-car modes, } \\
\text { compared with } 10 \% \text { of all other } \\
\text { employees in the local area }\end{array}$ & $\begin{array}{l}\text { Moderate: results are based on self- } \\
\text { reported travel survey data }\end{array}$ \\
\hline $\begin{array}{l}\text { Office (1 site) } \\
\text { Auckland, New Zealand (Baker 2007) }\end{array}$ & $\begin{array}{l}\text { Reduction in car driver trips by } \\
\text { employees of } 21 \text { percentage points, } \\
\text { from } 92 \% \text { in } 2004 \text { to } 71 \% \text { in } 2006\end{array}$ & $\begin{array}{l}\text { Moderate: results are based on self- } \\
\text { reported travel survey data; absence of } \\
\text { any control group }\end{array}$ \\
\hline $\begin{array}{l}\text { Employment (20 sites)* } \\
\text { United Kingdom (Cairns et al. 2010) }\end{array}$ & $\begin{array}{l}\text { Average reduction in commuter car } \\
\text { trips of } 14 \text { percentage points, or } 18 \% \text {; } \\
\text { sites with parking management } \\
\text { measures achieved a greater average } \\
\text { reduction of } 24 \%\end{array}$ & $\begin{array}{l}\text { Moderate: results are mostly based } \\
\text { on self-reported travel survey data; } \\
\text { lack of control sites }\end{array}$ \\
\hline $\begin{array}{l}\text { Residential (16 sites) } \\
\text { Arlington, United States (Arlington } \\
\text { County Commuter Services 2013) }\end{array}$ & $\begin{array}{l}\text { Vehicle trip generation was up to } 60 \% \\
\text { lower than published rates } \\
51 \% \text { of residents drove alone to work, } \\
\text { compared to } 54 \% \text { for the local area } \\
\text { and } 64 \% \text { for the wider region }\end{array}$ & $\begin{array}{l}\text { Low: published vehicle trip } \\
\text { generation rates are based on surveys } \\
\text { undertaken in different years and } \\
\text { locations to those at the } 16 \text { sites }\end{array}$ \\
\hline $\begin{array}{l}\text { Residential (8 sites) } \\
\text { London, United Kingdom (WSP } \\
\text { 2014) }\end{array}$ & $\begin{array}{l}\text { Car use at sites was } 10 \% \text { lower than } \\
\text { the average for the surrounding area }\end{array}$ & $\begin{array}{l}\text { Low: data is not comparable in terms } \\
\text { of survey periods ( } 2 \text { years apart) }\end{array}$ \\
\hline $\begin{array}{l}\text { Residential (4 sites) } \\
\text { Melbourne, Australia (De Gruyter et } \\
\text { al. 2015c) }\end{array}$ & $\begin{array}{l}\text { Car driver trips were } 14 \text { percentage } \\
\text { points lower ( } 23 \% \text { vs. } 37 \% \text { ) at sites } \\
\text { with travel plans compared to control } \\
\text { sites without travel plans }\end{array}$ & $\begin{array}{l}\text { High: data collected at a single point } \\
\text { in time, yet evaluation was } \\
\text { comprehensive and included the use } \\
\text { of control sites }\end{array}$ \\
\hline $\begin{array}{l}\text { New South Wales, Australia (Wiblin } \\
\text { et al. 2012) }\end{array}$ & $\begin{array}{l}\text { Car ownership of } 1.6 \\
\text { vehicles/household compared to } 2.0 \\
\text { vehicles/household for control } \\
\text { (surrounding) suburbs }\end{array}$ & $\begin{array}{l}\text { Moderate: control suburbs were not } \\
\text { directly comparable to the case site in } \\
\text { terms of accessibility to nearby } \\
\text { facilities }\end{array}$ \\
\hline
\end{tabular}




\begin{tabular}{|c|c|c|}
\hline Land use & Key findings & Level of evaluation rigour \\
\hline $\begin{array}{l}\text { Hospital (1 site) } \\
\text { New South Wales, Australia } \\
\text { (Petrunoff et al. 2016b) }\end{array}$ & $\begin{array}{l}\text { Driving to work among employees } \\
\text { decreased by } 13 \text { percentage points, } \\
\text { from } 83 \% \text { in } 2011 \text { to } 70 \% \text { in } 2014\end{array}$ & $\begin{array}{l}\text { Moderate: results are based on self- } \\
\text { reported travel survey data; absence of } \\
\text { any control group }\end{array}$ \\
\hline $\begin{array}{l}\text { Hospital (2 sites) } \\
\text { Perth, Australia (Petrunoff et al. 2015) }\end{array}$ & $\begin{array}{l}\text { Reduction in drive alone trips by } \\
\text { employees of } 42 \text { percentage points for } \\
\text { a site with parking management } \\
\text { measures, compared to a reduction of } \\
5 \text { percentage points for a site without } \\
\text { parking management measures }\end{array}$ & $\begin{array}{l}\text { High: relatively low survey response } \\
\text { rate (13-25\%) with self-reported } \\
\text { results, yet evaluation was very } \\
\text { comprehensive, with before and after } \\
\text { measurements and a control group } \\
\text { included }\end{array}$ \\
\hline $\begin{array}{l}\text { Hospital (2 sites) } \\
\text { United Kingdom (Potter \& Enoch } \\
\text { 2007) }\end{array}$ & $\begin{array}{l}\text { Reduction in drive alone trips by } \\
\text { employees of } 22-24 \text { percentage points }\end{array}$ & $\begin{array}{l}\text { Unclear: limited information } \\
\text { available on survey method although } \\
\text { results appear to be based on self- } \\
\text { reported travel survey data }\end{array}$ \\
\hline $\begin{array}{l}\text { University (1 site) } \\
\text { Hertfordshire, United Kingdom } \\
\text { (Copsey 2012) }\end{array}$ & $\begin{array}{l}\text { Reduction in drive alone trips by } \\
\text { employees of } 14 \text { percentage points, } \\
\text { from } 82 \% \text { in } 2002 \text { to } 68 \% \text { in } 2009\end{array}$ & $\begin{array}{l}\text { Moderate: results are based on self- } \\
\text { reported travel survey data; absence of } \\
\text { any control group }\end{array}$ \\
\hline $\begin{array}{l}\text { University (1 site) } \\
\text { Edinburgh, United Kingdom (Rye et } \\
\text { al. 2011b) }\end{array}$ & $\begin{array}{l}\text { Reduction in car trips by staff and } \\
\text { students of } 11 \text { percentage points, from } \\
50 \% \text { in } 2007 \text { to } 39 \% \text { in } 2009\end{array}$ & $\begin{array}{l}\text { Unclear: no information available on } \\
\text { survey method }\end{array}$ \\
\hline
\end{tabular}

Source: Authors' synthesis of the literature based on citations within the table

* Mix of employment related land uses; majority (not all) were required to have a travel plan as part of planning consent

In addition to those in Table 6, there may be other evaluations that have been conducted of travel plans for new developments that have not been reported. Reflecting on the range of issues associated with travel plans for new developments (identified earlier in Table 4), cases of less successful results may not have been published possibly because researchers and practitioners choose not to publish them or have difficulty publishing negative results (Bamberg \& Möser 2007; Richter et al. 2011). While the results in Table 6 are considered to represent a range of land uses in different jurisdictions, it is clear that there is a paucity of robust evidence concerning the effectiveness of travel plans for new developments (Addison \& Associates 2008; Rye et al. 2011b). Frequently, other factors are used as de facto success measures to evaluate the implementation of the travel plan. These include the provision of bicycle parking, 
walking routes, travel information and participation in travel planning activities coordinated by the local authority (a measure of engagement).

Based on the literature, Table 7 contains a summary of key factors associated with successful travel plans for new developments. Supportive policy has been cited as the most important factor among local authorities in the United Kingdom for requiring travel plans for new developments (Addison \& Associates 2008). Travel plans that contain car parking management measures, such as parking supply restrictions and parking fees, have also been associated with success (Cairns et al. 2010; De Gruyter et al. 2015c; Petrunoff et al. 2015). Ownership and engagement in the travel planning process has been identified as a key factor (De Gruyter 2017; Howlett \& Watson 2010), although this can be challenging for new developments (Yeates \& Enoch 2013). As noted by Harrison (2003, p. 400), ‘...the individual who may feel most committed to the travel plan, having drafted and negotiated it, may be the consultant who will have no further connection with the site once planning permission has been granted' (Harrison 2003). Other success factors include management support (Cairns et al. 2010; Petrunoff et al. 2013), provision of comprehensive travel plan measures (Cairns et al. 2004; Petrunoff et al. 2015; Vanoutrive 2014), an enthusiastic and dedicated travel plan coordinator (Enoch \& Rye 2006; Woodruff \& Hui 2010), clear roles and responsibilities (De Gruyter et al. 2015a), monitoring linked to financial penalties (De Gruyter et al. 2015b), and the provision of training and guidelines (De Gruyter 2017; De Gruyter et al. 2014b; Rye et al. 2011a). Many of these factors are common to both travel plans for existing developments and for those secured through the planning process. In addition, although dedicated funding is key to successful travel planning (Cairns et al. 2004; Ho et al. 2015; Wiblin et al. 2012), Orski (1993, p. 162) found that ' ...large expenditures do not always ensure program success, and lesser expenditures can sometimes be as effective, if appropriately targeted’ (Orski 1993). 
Table 7. Key factors associated with successful travel plans for new developments.

\begin{tabular}{|c|c|}
\hline Success factor & Supporting comments and evidence \\
\hline Supportive policy & $\begin{array}{l}\text { Most cited 'assisting' factor among local authorities in the United Kingdom in securing travel } \\
\text { plans for new developments (Addison \& Associates 2008); also supported by other related } \\
\text { literature (De Gruyter 2017; Department for Transport 2009; MAX 2007) }\end{array}$ \\
\hline $\begin{array}{l}\text { Car parking } \\
\text { management }\end{array}$ & $\begin{array}{l}\text { Widely cited as a key success factor for travel plans, with greater reductions in car use found with } \\
\text { travel plans that include car parking management measures (Cairns et al. 2010; De Gruyter 2017; } \\
\text { De Gruyter et al. 2015c; Petrunoff et al. 2015) }\end{array}$ \\
\hline $\begin{array}{l}\text { Ownership and } \\
\text { engagement }\end{array}$ & $\begin{array}{l}\text { Applies throughout the entire travel planning process, but ideally achieved through the target } \\
\text { group being specifically involved in the development of the travel plan (Howlett \& Watson 2010) }\end{array}$ \\
\hline $\begin{array}{l}\text { Management } \\
\text { support }\end{array}$ & $\begin{array}{l}\text { Particularly relevant to workplaces where management can lead by example; can also assist with } \\
\text { implementing controversial measures and/or where specific funding is required (Cairns et al. 2010; } \\
\text { Petrunoff et al. 2013) }\end{array}$ \\
\hline $\begin{array}{l}\text { Comprehensive } \\
\text { travel plan } \\
\text { measures }\end{array}$ & $\begin{array}{l}\text { Tailored measures that work together as an integrated package; a combination of incentives } \\
\text { ('carrots') to encourage the use of more sustainable transport modes, and disincentives ('sticks') to } \\
\text { discourage car use, is desirable (Cairns et al. 2004; Petrunoff et al. 2015; Vanoutrive 2014) }\end{array}$ \\
\hline $\begin{array}{l}\text { Enthusiastic and } \\
\text { dedicated travel } \\
\text { plan coordinator }\end{array}$ & $\begin{array}{l}\text { Commonly cited by the literature as a key success factor in travel planning (Enoch \& Rye 2006; } \\
\text { Woodruff \& Hui 2010); successful travel plan coordinators tend to have 'influencing' and 'steady' } \\
\text { working styles (Hendricks 2005) }\end{array}$ \\
\hline Dedicated funding & $\begin{array}{l}\text { Particularly important for the implementation phase, but also for monitoring purposes (Cairns et al. } \\
\text { 2004; Ho et al. 2015; Wiblin et al. 2012) }\end{array}$ \\
\hline $\begin{array}{l}\text { Clear roles and } \\
\text { responsibilities }\end{array}$ & $\begin{array}{l}\text { Relevant not only for implementation but also for specifying handover arrangements from the } \\
\text { developer to building/property manager (De Gruyter 2017; De Gruyter et al. 2015a) }\end{array}$ \\
\hline $\begin{array}{l}\text { Monitoring linked } \\
\text { to financial } \\
\text { penalties }\end{array}$ & $\begin{array}{l}\text { While the focus should be on compliance, mechanisms for imposing financial penalties for non- } \\
\text { compliance can help to ensure desired outcomes are achieved (De Gruyter 2017; De Gruyter et al. } \\
\text { 2015b) }\end{array}$ \\
\hline $\begin{array}{l}\text { Training and } \\
\text { guidelines }\end{array}$ & $\begin{array}{l}\text { Important that these are tailored to new developments and the local planning context (De Gruyter } \\
\text { 2017; De Gruyter et al. 2014b; Rye et al. 2011a) }\end{array}$ \\
\hline
\end{tabular}

Source: Authors' synthesis of the literature based on citations within the table

Despite the range of success factors for travel planning that have been cited, quantifying their relative effectiveness is difficult given the site-specific nature of travel planning and the influence of different travel plan coordinator working styles (Hendricks 2005). As noted by Orski (1993, p. 162) in the context of workplace travel plans, '...the effectiveness of [travel plans] depends to a large extent on intangible, difficult-to-quantify factors: the commitment of 
senior management, the aggressiveness with which the [travel plan] is promoted, and the status and visibility of the [travel plan coordinator]' (Orski 1993). It is also noted that in addition to those in Table 7, there may be other factors considered to be more important in particular circumstances given the location and site-specific nature of travel planning.

A further challenge in the evaluation of travel plans secured through the planning process is to get a good picture of how consistently they have been required across a city or country. Given experience, many local authorities in the United Kingdom have changed their approach over time, with certain areas applying more stringent controls and developing Supplementary Planning Guidance to support the process when it has become evident that earlier travel plans for new developments were ineffective. Addison \& Associates (2008) and Rye et al. (2011a) both raise this issue. Different councils and within them different planning officials will take differing lines on the use of travel plans in new developments; while one may simply require a document to be submitted to satisfy its policy, another may secure mode share targets, annual monitoring and a bond for underperformance against those targets. This will inevitably affect the aggregate effectiveness of this way of using the planning system.

\section{Discussion and conclusions}

This research has provided an international synthesis of research on travel plans for new developments. Based on the findings, this section provides some recommendations to guide future practice and policy.

First, the literature revealed a number of differences between the characteristics of travel plans for pre-existing sites and those for new developments. Therefore, a conventional approach to travel planning, as used at pre-existing sites, should not be automatically replicated at new developments. In particular, greater consideration will typically need to be given to infrastructure-based travel plan measures to ensure these will are in place prior to site 
occupation. Specific processes for managing the travel plan will also need to be considered, particularly where the travel plan is to be handed over from the property developer to an ongoing travel plan coordinator based at the site. In addition, monitoring and review of the travel plan may include specific requirements to regularly report outcomes to the relevant local authority as part of a planning condition/agreement for the site. Guidance on travel plans for new developments, such as that from the United Kingdom (Department for Transport 2009; Transport for London 2011), should also reflect and highlight these differences. Even within such guidance in place, though, travel plans at new developments present considerable challenges, especially when the end user of the new development is not known at the time of the granting of planning permission.

Second, a range of approaches to securing travel plans for new developments was evident from the literature. The United Kingdom has traditionally had national planning policy in place that is supportive of travel plans (Rye et al. 2011a), but this has then been complemented by supplementary planning guidance (effectively part of the local development plan) at the local level. On the other hand, countries such as the United States have required travel plans more at the local level (Jollon 2013) but without state level guidance in most instances. In countries such as Australia, Canada and New Zealand - where travel planning for new developments is still an emerging field - efforts should be directed towards understanding which approaches are most appropriate in different contexts. As part of this, the experiences of the United Kingdom and United States with travel planning should be considered and adapted as needed to ensure best possible outcomes.

Third, while the findings from previous evaluations revealed considerable variability, most found a reduction in car driver trips of around 10-20 percentage points. This is generally consistent with previous research by Enoch \& Rye (2006) into the effectiveness of travel plans for pre-existing sites, noting a reduction in car driver trips of $15 \%$ or when including financial 
disincentives to car use (Enoch \& Rye 2006). Despite this level of comparability, there is a paucity of robust evidence concerning the effectiveness of travel plans for new developments. Efforts therefore need to be directed towards ensuring greater rigour in future evaluations, while ensuring that these can still be conducted in a pragmatic way (Petrunoff et al. 2016a). The literature review also highlighted a number of success factors for travel plans for new developments. These factors should be embedded within the travel planning process where possible to ensure best outcomes for new developments.

Fourth, and while not explicitly linked to the findings from this literature review, different jurisdictions within cities and countries will take different approaches to securing travel plans through the planning process, responding to different transport, land use, social, institutional, political and economic contexts (MAX 2007). This will affect the degree to which consistent impacts from such travel plans can be expected on aggregate across a wider geographical area. Some developments may have extremely effective plans that have been secured through the planning system, but this is unlikely to be the case for all developments even of the same land use class and size in the same local authority area.

While considerable effort was made to source all relevant literature for this review, there may a number of undocumented but relevant practices that are not captured by this paper. This is particularly relevant for evaluations of travel plans where less successful results may not have been published (Bamberg \& Möser 2007; Richter et al. 2011). Here, there may be cases of where travel plans were not evaluated independently (i.e. the evaluation was undertaken by the same firm/body responsible for implementation), as has occurred in the context of some personalised journey planning programs (James et al. 2017; Möser \& Bamberg 2008). However, strengths and contributions of this literature review include a number of syntheses on different aspects of travel plans for new developments, previously not available. These syntheses have helped to understand past and current trends in travel planning for new 
developments, thereby informing the development of recommendations to guide future policy and practice in this field.

Reflecting on the objectives stated on the beginning of this paper, it is now possible to draw some further conclusions about the research:

Objective 1: To develop an understanding of their key characteristics and issues associated with their development, implementation and monitoring

While travel plans for new developments share a common set of elements with those for pre-existing sites, differences within each element are notable, particularly in the types of travel plan measures adopted, processes for managing the travel plan, and approaches to monitoring and review. Key issues with requiring travel plans for new developments include varying quality in travel plans that are submitted, and in some cases, a lack of implementation and monitoring. On the other hand, certainly in some jurisdictions, because travel plans for new developments are linked to a legal mechanism, the planning process, this can give the local authorities mechanisms to secure travel planning activities that are simply unavailable in the case of existing developments. For example, it is problematic to influence the supply or management of car parking in existing developments but this is not the case for new developments. Equally, it is easier to influence the provision of other supporting sustainable transport infrastructure for new developments when these are a requirement of planning consent.

Objective 2: To understand where and how they have been required through the planning process, and the implications this has for travel planning practice

Travel plans are mainly required for new developments in the United Kingdom, United States, continental Europe and Australia. The United Kingdom are arguably the leaders in the field with a supportive national and local policy framework in place, although 
the United States also has strong policy support for travel plans at the local level in some counties and cities. Mechanisms used to require travel plans have generally comprised of planning conditions and different forms of legal agreements. Key implications of this include the need to ensure the approach used to require travel plans is always appropriately tailored to the local context, and that this may affect the degree to which consistent impacts can be expected given the presence of different contexts.

Objective 3: To synthesise previous evaluations of their effectiveness and identify key success factors

Results of previous evaluations of travel plans for new developments have varied considerably, with decreases in car driver trips ranging from 5-42 percentage points. Key success factors also vary although common elements include supportive policy, car parking management measures, and ownership and engagement in the travel planning process.

Although the planning process is a potentially quite powerful way to secure travel plans, there remain a number of uncertainties and challenges in using it to do so. These include:

- The degree to which it is possible (or not) to use these processes to secure a consistent level of travel planning across all new developments in a geographical area, with travel plans with a similar level of potential impact (meaning similar measures)

- The challenges of using legal frameworks in which it is sometimes hard to find a place for travel plans and their objectives

- The need for and nature of policy frameworks at both central and local government levels that are supportive of travel planning through the planning process

- The level of knowledge and capacity required in local authority teams dealing with 
planning applications so that they know how to and have the resources to secure travel plans

- The interrelationship between travel planning and (maximum) parking standards for new developments.

Acting on the recommendations outlined in this paper, along with continued research efforts in the field, should assist in providing more evidence and experience to deal with these challenges and thus to help in moving travel plans towards achieving the potential that they can realise when they are required as part of the land use planning and approvals process.

\section{References}

ABC 2014, Establishing an Effective Commute Trip Reduction Policy in Massachusetts, A Better City (ABC), Massachusetts, United States.

ACT Canada \& Noxon Associates Limited 2010, Workplace Travel Plans: Guidance for Canadian Employers, Transport Canada, Ottawa, Canada.

Addison \& Associates 2008, Delivering travel plans through the planning process - Research report, Department for Transport and Communities and Local Government, London, United Kingdom.

Ampt, ES, Richardson, AJ \& Wake, D 2009, 'Simple and suited: Guidelines for workplace travel surveys', paper presented to 32nd Australasian Transport Research Forum (ATRF), Auckland, New Zealand.

Angelo Planning Group \& Nelson Nygaard 2013, Transportation Demand Management (TDM) Plans for Development, Oregon Department of Transportation and Oregon Department of Land Conservation and Development, Oregon, United States. 
Arlington County Commuter Services 2013, Residential Building Transportation

Performance Monitoring Study, Arlington, Virginia, United States.

ATOC 2013, Guidance on the implementation of Station Travel Plans, Association of Train Operating Companies, United Kingdom.

Baker, L 2007, 'Workplace travel plans - a new rule of the game', paper presented to New Zealand Planning Institute and EAROPH conference, Palmerston North, New Zealand.

Bamberg, S \& Möser, G 2007, 'Why are work travel plans effective? Comparing conclusions from narrative and meta-analytical research synthesis', Transportation, vol. 34, no. 6, pp. 647-66.

British Standards Institution 2008, PAS 500: 2008 - National specification for workplace travel plans London, United Kingdom.

Brög, W, Erhard, E, Ker, I, Ryle, J \& Wall, R 2009, 'Evaluation of voluntary travel behaviour change: Experiences from three continents', Transport Policy, vol. 16, no. 6, pp. 281-92.

Cairns, S, Davis, A, Newson, C \& Swiderska, C 2002, Making travel plans work: Research report, Department for Transport, London, United Kingdom.

Cairns, S, Newson, C \& Davis, A 2010, 'Understanding successful workplace travel initiatives in the UK', Transportation Research Part A: Policy and Practice, vol. 44, no. 7, pp. 473-94.

Cairns, S, Sloman, L, Newson, C, Anable, J, Kirkbride, A \& Goodwin, P 2004, Smarter Choices - Changing the way we travel, Department for Transport, United Kingdom.

City and County of San Francisco 2016a, Planning Code Amendment Initiation, Executive Summary, San Francisco Planning Department, San Francisco, United States. 
City and County of San Francisco 2016b, Standards for the Transportation Demand Management Program, San Francisco Planning Department, San Francisco, United States.

Coleman, C 2000, 'Green commuter plans and the small employer: an investigation into the attitudes and policy of the small employer towards staff travel and green commuter plans', Transport Policy, vol. 7, no. 2, pp. 139-48.

Copsey, S 2012, 'The development and implementation processes of a travel plan within the context of a large organisation: Using an embedded case study approach', $\mathrm{PhD}$ thesis, University of Hertfordshire.

Currie, G \& Delbosc, A 2011, 'Travel Demand Management for the Summer Olympic Games', Transportation Research Record: Journal of the Transportation Research Board, no. 2245, pp. 36-48.

Curtis, C \& Holling, C 2004, 'Just how (Travel) Smart are Australian universities when it comes to implementing sustainable travel?', World Transport Policy and Practice, vol. 10, no. 1 , pp. 22-33.

De Gruyter, C 2017, Travel Plans for New Residential Developments: Insights from Theory and Practice, Springer Theses, Springer, Singapore.

De Gruyter, C, Rose, G \& Currie, G 2014a, 'Methodology for Evaluating Quality of Travel Plans for New Developments', Transportation Research Record: Journal of the Transportation Research Board, no. 2417, pp. 46-57.

De Gruyter, C, Rose, G \& Currie, G 2014b, 'Securing travel plans through the planning approvals process: A case study of practice from Victoria, Australia', Cities, vol. 41, Part A, pp. 114-22. 
De Gruyter, C, Rose, G \& Currie, G 2015a, 'Enhancing the impact of travel plans for new residential developments: Insights from implementation theory', Transport Policy, vol. 40, pp. 24-35.

De Gruyter, C, Rose, G \& Currie, G 2015b, 'Travel plans for new residential developments: A synthesis of research findings', Road and Transport Research: A Journal of Australian and New Zealand Research and Practice, vol. 24, no. 4, pp. 59-72.

De Gruyter, C, Rose, G \& Currie, G 2015c, 'Understanding Travel Plan Effectiveness for New Residential Developments', Transportation Research Record: Journal of the Transportation Research Board, no. 2537, pp. 126-36.

De Gruyter, C, Rose, G \& Currie, G 2016, 'Travel Plans for New Residential Developments: Measuring Self-Selection Effects to Better Understand Travel Behavior Impacts', Transportation Research Record: Journal of the Transportation Research Board, no. 2564, pp. 60-9.

Department for Transport 2005, A guide on travel plans for developers, Transport Energy, Energy Saving Trust, United Kingdom.

Department for Transport 2009, Good Practice Guidelines: Delivering Travel Plans through the Planning Process, Department for Transport, London, United Kingdom.

Department of Infrastructure 2008, TravelSmart travel planning guide, Victoria, Australia.

Dill, J 1998, 'Mandatory Employer-Based Trip Reduction: What Happened?', Transportation Research Record: Journal of the Transportation Research Board, no. 1618, pp. 103-10.

Enoch, M 2012, Sustainable Transport, Mobility Management and Travel Plans, Ashgate Publishing Limited, Surrey, England. 
Enoch, M \& Ison, S 2008, Expert Perspectives on the Past, Present and Future of Travel Plans in the UK: Research Report, Department for Transport and the National Business Travel Network, United Kingdom.

Enoch, M \& Potter, S 2003, 'Encouraging the commercial sector to help employees change their travel behaviour', Transport Policy, vol. 10, no. 1, pp. 51-8.

Enoch, M \& Rye, T 2006, 'Travel plans: Using good practice to inform future policy', in B Jourquin, P Rietveld \& K Westin (eds), Towards better performing transport networks, Routledge, London, United Kingdom, pp. 157-77.

Gammie, F \& Vandersar, D 2003, 'Voluntary employer transport plans: can they work in New Zealand?', paper presented to 26th Australasian Transport Research Forum (ATRF), Wellington, New Zealand.

Guiver, J \& Stanford, D 2014, 'Why destination visitor travel planning falls between the cracks', Journal of Destination Marketing \& Management, vol. 3, no. 3, pp. 140-51.

Harrison, J 2003, 'Travel plans and the planning system', Journal of Planning and Environment Law, no. April 2003, pp. 397-403.

Hendricks, S 2005, 'Effectiveness of programs for work site trip reduction: The influence of organisational culture', Transportation Research Record: Journal of the Transportation Research Board, no. 1924, pp. 207-14.

Hendricks, S 2008, 'Four challenges to Incorporating Transportation Demand Management into the Land Development Process', Transportation Research Record: Journal of the Transportation Research Board, no. 2046, pp. 30-6.

Hill, J 2013, Proposed Modifications to the Regional Transportation Impact Study Guidelines - Public Meeting, Report P-13-031, Region of Waterloo, Ontario, Canada. 
Ho, C, Mulley, C, Tsai, C-H, Ison, S \& Wiblin, S 2015, 'Area-wide travel plans - targeting strategies for greater participation in green travel initiatives: a case study of Rouse Hill Town Centre, NSW Australia', Transportation, vol. 44, no. 2, pp. 325-52.

Howlett, R \& Watson, T 2010, 'Travel planning in Victoria - a new strategic approach to sustaining communities', paper presented to 33rd Australasian Transport Research Forum (ATRF), Canberra, Australia.

Ison, S, Merkert, R \& Mulley, C 2014, 'Policy approaches to public transport at airports Some diverging evidence from the UK and Australia', Transport Policy, vol. 35, pp. 265-74.

James, B, Burke, M \& Yen, BTH 2017, 'A critical appraisal of Individualised Marketing and Travel Blending interventions in Queensland and Western Australia from 1986-2011', Travel Behaviour and Society, vol. 8, pp. 1-13.

Jollon, M 2013, 'Best Practices in Integrating Travel Plans with the Development Approval Process: Examples from the USA', paper presented to Planning Institute of Australia (PIA) 2013 National Congress, Canberra, Australia.

Khandokar, F, Ryley, T, Ison, S \& Price, A 2013, 'A survey on hospital travel plans in England', paper presented to 92nd Transportation Research Board (TRB) Annual Meeting, Washington D.C., United States.

Llewellyn, R, Tricker, R \& Paton, D 2014, 'Travel plans: A critical comparison of the application of land use planning processes in England and Scotland', Transport, no. iFirst, pp. $1-13$.

Macmillan, A, Hosking, J, Connor, J, Bullen, C \& Ameratunga, S 2013, 'A Cochrane systematic review of the effectiveness of organisational travel plans: Improving the evidence base for transport decisions', Transport Policy, vol. 29, pp. 249-56. 
MAX 2007, WP D Working Stage: Analysis - Cross national comparison of integration of sustainable transport, mobility management and land use planning in 10 European countries Sixth Framework Programme, European Commission, Brussels, Belgium.

MAX 2009, WP D Integrating Mobility Management and Land Use Planning: Final Report, Sixth Framework Programme, European Commission, Brussels, Belgium.

Melia, S, Barton, H \& Parkhurst, G 2013, 'Potential for carfree development in the UK', Urban Design and Planning, vol. 166, no. DP2, pp. 136-45.

Moghtaderi, F, Burke, M \& Dodson, J 2012, 'A systematic review of children's travel behaviour change programs in Australia', paper presented to 35th Australasian Transport Research Forum (ATRF), Perth, Australia.

Möser, G \& Bamberg, S 2008, 'The effectiveness of soft transport policy measures: A critical assessment and meta-analysis of empirical evidence', Journal of Environmental Psychology, vol. 28 , no. 1 , pp. 10-26.

NSW Government 2011, Active Travel: Optus Relocation, New South Wales, Australia.

NZ Transport Agency 2011, Workplace travel plan guidelines, New Zealand Government, Wellington, New Zealand.

Orski, CK 1993, 'Evaluation of Employee Trip Reduction Programs Based on California's Experience with Regulation XV', paper presented to 1993 ITE International Conference, Orlando, Florida, United States.

PBAI 2005, Guidelines for the Application and Implementation of Travel Plans for New Development in Darebin, City of Darebin, Victoria, Australia. 
Petrunoff, N, Rissel, C, Wen, LM \& Martin, J 2015, 'Carrots and sticks vs carrots: Comparing approaches to workplace travel plans using disincentives for driving and incentives for active travel', Journal of Transport \& Health, vol. 2, no. 4, pp. 563-7.

Petrunoff, N, Rissel, C \& Wen, LW 2016a, 'The effect of active travel interventions conducted in work settings on driving to work: A systematic review', Journal of Transport \& Health, vol. 3, no. 1, pp. 61-76.

Petrunoff, N, Rissel, C, Wen, LW, Xu, H, Meiklejohn, D \& Schembri, A 2013, 'Developing a hospital travel plan: process and baseline findings from a western Sydney hospital', Australian Health Review, vol. 37, no. 5, pp. 579-84.

Petrunoff, N, Wen, LM \& Rissel, C 2016b, 'Effects of a workplace travel plan intervention encouraging active travel to work: outcomes from a three-year time-series study', Public Health, vol. 135, pp. 38-47.

Potter, S \& Enoch, M 2007, 'Mobility Management in Organisations', in JP Warren (ed.), Managing Transport Energy: Power for a sustainable future, Oxford University Press, Oxford, United Kingdom, pp. 93-120.

RAC 2014, Travel planning for new developments: Advice for local governments, RAC Mobility Bulletin \#01, Perth, Australia.

Richter, J, Friman, M \& Gärling, T 2011, 'Soft Transport Policy Measures: Gaps in Knowledge', International Journal of Sustainable Transportation, vol. 5, no. 4, pp. 199-215.

Roby, H 2010a, 'Using innovation and business models to analyse the organisational embedding of travel plans', PhD thesis, Open University.

Roby, H 2010b, 'Workplace travel plans: past, present and future', Journal of Transport Geography, vol. 18, no. 1, pp. 23-30. 
Rose, G \& Ampt, E 2001, 'Travel blending: an Australian travel awareness initiative', Transportation Research Part D: Transport and Environment, vol. 6, no. 2, pp. 95-110.

Rye, T, Green, C, Young, E \& Ison, S 2011a, 'Using the land-use planning process to secure travel plans: an assessment of progress in England to date', Journal of Transport Geography, vol. 19, no. 2, pp. 235-43.

Rye, T, Welsch, J, Plevnik, A \& de Tomassi, R 2011b, 'First steps towards cross-national transfer in integrating mobility management and land use planning in the EU and Switzerland', Transport Policy, vol. 18, no. 3, pp. 533-43.

Seggerman, K \& Hendricks, S 2005, Incorporating TDM into the Land Development Process, Department of Transportation, Florida, United States.

Smith, L 2010, 'School travel plans: how successful are they?', Traffic Engineering and Control, no. May 2010, pp. 189-93.

Spack, M, Bultman, M, Pettis, K, Thompson, J \& Collins, J 2010, Travel Demand Management: An Analysis of the Effectiveness of TDM Plans in Reducing Traffic and Parking in the Minneapolis-St. Paul Metropolitan Area, Spack Consulting, Minnesota, United States.

Stewart, J 1994, 'Reducing Drive-Alone Rates at Small Employer Sites: Costs and Benefits of Local Trip Reduction Ordinances - Pasadena Towers Case Study', Transportation Research Record: Journal of the Transportation Research Board, no. 1433, pp. 159-63.

Transport for London 2011, Travel planning for new development in London - incorporating deliveries and servicing, Transport for London, United Kingdom. 
UrbanTrans \& Kimley Horn Associates 2014, City of Boulder Developer TDM

Requirements: Best Practices Research, City of Boulder, Colorado, United States.

Van Wee, B \& Banister, D 2016, 'How to write a literature review paper?', Transport

Reviews, vol. 36, no. 2, pp. 278-88.

Vanoutrive, T 2014, 'Workplace travel plans: can they be evaluated effectively by experts?', Transportation Planning and Technology, vol. 37, no. 8, pp. 757-74.

Vanoutrive, T, Van Malderen, L, Jourquin, B, Thomas, I, Verhetsel, A \& Witlox, F 2010, 'Mobility Management Measures by Employers: Overview and Exploratory Analysis for Belgium', European Journal of Transport Infrastructure and Research, vol. 10, no. 2, pp. $121-41$.

Wake, D 2007, 'Managing travel to a major health campus: Travel plan for QEII Medical Centre', paper presented to 30th Australasian Transport Research Forum, Melbourne, Australia.

Wiblin, S, Mulley, C \& Ison, S 2012, 'Precinct wide travel plans - learnings from Rouse Hill Town Centre', paper presented to 35th Australasian Transport Research Forum (ATRF), Perth, Australia.

Woodruff, A \& Hui, C 2010, 'Integrating planning in activity centres: influencing change across all travel purposes', paper presented to 33rd Australasian Transport Research Forum (ATRF), Canberra, Australia.

Wright, L 2005, Sustainable Transport: A Sourcebook for Policy-makers in Developing Cities Module 3e Car-Free Development, Deutsche Gesellschaft fur Technische Zusammenarbeit (GTZ) GmbH, Federal Ministry for Economic Cooperation and Development, Eschborn, Germany. 
WSP 2014, Does car ownership increase car use? A study of the use of car parking within residential developments in London, Commissioned by the Berkeley Group, United Kingdom.

Wynne, L 2015, 'Can we integrate land-use and transport planning? An investigation into the use of travel planning in regulation', paper presented to 21st International Conference on Urban Transport and the Environment, Valencia, Spain.

Yeates, S \& Enoch, M 2013, 'Travel plans from the developer perspective', Proceedings of the Institution of Civil Engineers: Urban Design and Planning, vol. 166, no. 5, pp. 262-73. 